\title{
An evaluation of the crop-physiological and epidemiological information in EPIPRE
}

\author{
by H. DRENTH*, J. HOEK $\dagger$, R. A. DAAMEN $\ddagger$, W. A. H. ROSSING $\S$, W. STOL† and \\ F. G. WIJNANDS ף \\ * Research Station for Arable Farming and Field Production of Vegetables (PAGV), \\ PO Box 430, 8200 AK Lelystad (The Netherlands) \\ $\dagger$ Netherlands Grain Centre (NGC), Costerweg 5, 6702 AA Wageningen (The Netherlands) \\ $\$$ Research Institute for Plant Protection (IPO), PO Box 9060, $6700 \mathrm{GW}$ Wageningen \\ (The Netherlands) \\ $\S$ Department of Theoretical Production Ecology, Agricultural University, PO Box 430 , \\ 6700 AK Wageningen (The Netherlands) \\ If EEC, PO Box 430, 8200 AK Lelystad (The Netherlands)
}

\begin{abstract}
EPIPRE is an integrated pest and disease management system for wheat based on on-line calculations of costs and benefits of pesticide treatments. It is field-specific and utilizes disease and pest incidences which are collected by the participating farmers. Incidences are transformed to severities through pest-specific relations with which a prediction of the epidemic is made according to an exponential development model. Integration of the epidemic over time, with multiplication by a pest-specific damage factor, delivers the expected damage till the end of the season, expressed as a fraction of the expected yield. Chemical control is only recommended when benefit of control exceeds total costs, including those for pesticide(s), labour, machinery and wheel-track damage. The current model needs improvement especially for the forecast of septoria blotch diseases, the field-specific quantification of the relative growth rates used and the damage relations of Puccinia strifformis and Mycosphaerella graminicola/Leptosphaeria nodorum. Also the cost-benefit analysis of the model can be improved, and it therefore, in the near future, needs contributions from research topics such as phytopathology, crop physiology, farm economics and information management. Using the model during the last 10 years has led to a reduced input of pesticides, which in its turn results in a lowering of production costs and a marked decrease in environmental pollution. Therefore future efforts to improve the model seem to be worthwhile.
\end{abstract}

\section{Historical context}

EPIPRE, an acronym for EPIdemic PREdiction or PREvention, is a computer-based advisory system for supervised control of pests and diseases in spring and winter wheat. Its development started in 1977 as a project of the Department of Phytopathology of the Agricultural University of Wageningen (NL) and the Netherlands Grain Centre. Initially its aim was to generate recommendations on chemical control of stripe rust (Puccinia striiformis) on individual fields of winter wheat. Later, the Department of Theoretical Production Ecology of the Agricultural University, the Research Institute for Plant Protection (IPO, Wageningen) and the Research Station for Arable Farming (PAGV, Lelystad) joined in. From 1982, further development of the system and support of the participants was achieved by the joint efforts of fundamental and applied research organizations and the extension service. The advisory model which resulted from the collaboration was tested and used on a routine basis by voluntarily participating wheat farmers.

The system was introduced when cropping practice in wheat was changing considerably. New systemic fungicides were made available for control of diseases in wheat. Concomitantly, 
agronomic practices with high pesticide and fertilizer input became popular, such as the Schleswig-Holstein system named after its German region of origin. In 1975 and 1977, major epidemics of stripe rust ( $P$. striiformis var. striiformis) occurred, causing losses of millions of guilders. The high disease pressure, and the opinion that acceptable disease control could be achieved with lower fungicide input, induced the initiation of EPIPRE (Rabbinge \& Rijsdijk, 1983).

Farmers participate with one or more fields. Participants are asked to supply field-specific information at the onset of the growing season and pest and disease incidence counts during the season. The information is passed to the central computer facility by telephone, the data are evaluated on-line by a computer model and the recommendation is communicated to the farmer during the same telephone call. Though started as a system for P. striiformis only, the advisory model was expanded over the years and currently comprises the major pests and diseases in winter wheat in The Netherlands: eyespot (Pseudocercosporella herpotrichoides); stripe rust (Puccinia striiformis); leaf rust (Puccinia recondita); powdery mildew (Erysiphe graminis); leaf blotch (Mycosphaerella graminicola); glume blotch (Leptosphaeria nodorum); aphids (Sitobion avenae, Metopolophium dirhodum and Rhopalosiphum padi).

To date, system development and support required approximately 45 labour years. Although this constitutes an effort of considerable size, the costs seem to be in proportion to the benefits (Zadoks, 1984). At the farm level, savings due to reduced inputs of pesticides in grains and possibly also in other crops can be ascribed to EPIPRE. On a nation-wide scale, the system reduced (future) costs of environmental damage and contributed to the dissemination of the concept of supervised control, for example in agricultural colleges. Rossing et al. (1985) concluded that the investment made for the development of the system up to 1980 has at least repaid itself.

The philosophy of EPIPRE is that control is only needed when benefits of control (i.e. losses not incurred) at least equal costs of machine use, labour, pesticides and wheel damage. In this way EPIPRE contributes to a reduction of pesticide use without affecting net crop yield.

Since its introduction in 1977, approximately 2000 Dutch farmers have participated in EPIPRE (Table 1), the majority for more than 1 year.

In Table 2 the relative importance of the various pests and diseases is listed, based on recommendations communicated to the participants from 1982 to 1987 . Different diseases

Table 1. Number of farmers and fields participating in EPIPRE from 1978 to 1987

Nombre d'agriculteurs, et de parcelles, pris en compte par EPIPRE de 1978 à 1987

\begin{tabular}{ccr}
\hline Year & Farmers & Fields \\
\hline 1978 & 300 & 411 \\
1979 & 300 & 450 \\
1980 & 520 & 840 \\
1981 & 617 & 1155 \\
1982 & 580 & 1069 \\
1983 & 650 & 1380 \\
1984 & 600 & 1100 \\
1985 & 460 & 816 \\
1986 & 453 & 862 \\
1987 & 325 & 703 \\
& & \\
Total & 4805 & \\
\hline
\end{tabular}


dominate in different years: 1983 was a leaf-rust year, in 1984 powdery mildew was the major pathogen whereas in 1987 most recommendations was directed against the blotches. Disease intensity was low in 1982 and 1986.

Apart from reduction of costs of wheat production and of pesticide use, a number of other positive effects can be attributed to EPIPRE. Participating farmers are trained in recognizing the symptoms of the various diseases through regional meetings with plant pathology experts. This aspect of information transfer is highly appreciated by participants (Blokker, 1982). From 1984 onwards information on the pest and disease situation has been disseminated to the whole farming community by publishing status reports in regional and national agricultural media. In these reports, disease development observed by EPIPRE farmers during the previous 2 weeks is described. Also information on cultivars and chemicals is supplied. With EPIPRE a link is established between research and farming practice, so that results of research projects can be channelled efficiently to farmers. On the other hand, EPIPRE can also reveal gaps in information necessary for decisions on pest and disease control. The results of a study are presented here in which the crop physiological and epidemiological relations used in EPIPRE are evaluated (Daamen et al., 1987).

\section{From field observation to damage prognosis}

\section{Sampling procedure}

The prediction of expected damage is based on information on the actual pest and disease incidence in the crop. This information is supplied by the participating farmer who collects tillers from his field, according to a standard procedure. This involves pulling 40 culms along the diagonal of the field and counting the number of leaves with a specific disease. From ear emergence onwards, the farmer also inspects 100 culms for the presence of aphids. The period during which counts of the various pests and diseases are to be made is represented in Table 3 , together with the nature of the sample. The interval between two observations is determined by the development stage of the crop and the size of the epidemic or infestation in the previous sample. A recommendation not to spray while disease intensity is relatively high is accompanied by a request to monitor again after a short period of time, usually one week.

Table 2. Recommendations given to participants of EPIPRE in the period 1982-87 Nombre de recommandations adressées aux abonnés du système EPIPRE en 1982-87

\begin{tabular}{lrrrrrr}
\hline Year & 1982 & 1983 & 1984 & 1985 & 1986 & 1987 \\
\hline $\begin{array}{l}\text { Number of participating fields } \\
\text { Number of recommendations per field }\end{array}$ & 1069 & 1380 & 1100 & 816 & 862 & 586 \\
$\begin{array}{l}\text { Recommendations to carry out chemical } \\
\quad \text { control (\% of number per field) }\end{array}$ & 19.5 & 42.1 & 39.6 & 35.6 & 22.6 & 42.1 \\
$\begin{array}{l}\text { \% of fields recommended for chemical } \\
\quad \text { control against eyespot }\end{array}$ & & & & & & \\
stripe rust & 0.0 & 5.6 & $10 \cdot 1$ & 9.6 & 7.0 & 12.5 \\
leaf rust & 0.0 & 7.5 & 3.0 & 2.0 & 2.0 & 9.5 \\
powdery mildew & 0.0 & 17.5 & 3.0 & 5.0 & 6.0 & 12.2 \\
$\quad$ blotches & 13.1 & 62.7 & 99.0 & 53.3 & 36.0 & 44.5 \\
aphids & 10.9 & 37.1 & 36.5 & 47.5 & 38.0 & 118.6 \\
& 51.2 & 31.4 & 38.2 & 44.0 & 33.0 & 41.8 \\
\hline
\end{tabular}


Table 3. Crop development stages (decimal code) at which monitoring for the various pests and diseases in winter wheat in The Netherlands is recommended by EPIPRE, and unit and size of recommended samples Stades phénologiques (code décimal) auxquels EPIPRE recommande de noter les divers ennemis du blé d'hiver, et nature et dimension de l'échantillon

\begin{tabular}{|c|c|c|c|c|c|c|c|}
\hline \multirow[b]{2}{*}{ Pest/disease } & \multicolumn{5}{|c|}{$\begin{array}{l}\text { Crop development } \\
\text { stages }\end{array}$} & \multirow[b]{2}{*}{ Sampling unit } & \multirow[b]{2}{*}{ Sample size } \\
\hline & 30 & 32 & 39 & 55 & $69 \quad 75$ & & \\
\hline Eyespot & \multicolumn{5}{|c|}{$* * * * * * *$} & base of tiller & 40 \\
\hline Powdery mildew & \multicolumn{5}{|c|}{$* * * * * * * * * * * * * * * * * * * * * * * *$} & top three leaves & 120 \\
\hline Stripe rust & \multicolumn{5}{|c|}{$* * * * * * * * * * * * * * * * * * * * * * *$} & all green leaves & $200^{1}$ \\
\hline Leaf rust & \multicolumn{5}{|c|}{$* * * * * * * * * * * * * * * * * * * * * * * * * * * * *$} & all green leaves & $200^{1}$ \\
\hline Blotches & \multicolumn{5}{|c|}{$* * * * * * * * * * * *$} & top three leaves & 120 \\
\hline Aphids & \multicolumn{5}{|c|}{$* * * * * * * * * * * *$} & culm & 100 \\
\hline
\end{tabular}

${ }^{1}$ Maximum number.

\section{Prediction of progress of the epidemic}

First the incidence counts obtained from the participants are transformed into severity, i.e. number of pustules per leaf, percentage leaf area or number of aphids per tiller. All transformations are based on the model proposed by Nachman (1981). Parameter values are estimated from field experiments for each damaging organism. The increase in density is predicted using an exponential model:

$$
Y_{\mathrm{t}}=\mathrm{Y}_{0} * \mathrm{e}^{\left(\mathrm{rgr}{ }^{*}\right)}
$$

where: $Y_{0}=$ pest or disease density sampled (leaf ${ }^{-1}$ or tiller $\left.^{-1}\right) ; Y_{t}=$ pest or disease density after time $t\left(\right.$ leaf $^{-1}$ or tiller $\left.^{-1}\right) ;$ rgr $^{\prime}$ field and organism-specific relative growth rate of the population $\left(\right.$ day $\left.^{-1}\right) ; t=$ forecasting period (day).

Exponential growth is assumed to peak at a certain density after which the population size remains constant up to GS 83 (early doughy ripe). Thereafter the crop is no longer suitable for pests or diseases and population densities are assumed to be zero.

The forecasting period is determined by a relation derived from field experiments describing the rate of crop development. Variations in development rate due to sowing rate or yield level are not taken into account.

The relative growth rate of the population depends on the damaging species, the crop development stage, the sensitivity of the cultivar, the soil type (for powdery mildew) and the use of growth regulators (for blotches). The nitrogen content of the crop determines to a large extent the rate of increase of pests and diseases. From the information on the expected yield level of a specific crop, its nitrogen content is calculated, which is used to modify the relative growth rate for stripe rust, powdery mildew and aphids.

The presence of active residue of one or more pesticides at the time of sampling is taken into account by assuming the relative growth rate of all pests and diseases concerned to be zero during the residue period. For benzimidazoles, the residue period is 10 days, for triazoles and morpholines 21 days and for pirimicarb 3 days.

\section{Forecasting damage}

The effect of the disease and aphids on grain yield is expressed as the fraction of yield expectation lost per unit of the organism per day (e.g. pustule-day per leaf or aphid-day per culm). For each 
pest or disease present, this relation is multiplied by the predicted density of the organism and integrated over time. In this way a forecast of total damage is obtained in terms of fraction of the expected yield.

As pointed out, 'expected yield' is one of the inputs supplied by the farmer. EPIPRE checks the expectation with the actual situation in the field by using the result of the farmer's count of the number of tillers at GS 45 (late boot). From the number of tillers and average values for the number of grain per ear and the average grain weight, an estimation is made of the attainable yield. If necessary, the EPIPRE estimate of expected yield replaces that supplied by the farmer.

\section{Recommendation}

In accordance with the philosophy of supervised pest and disease management, chemical control is only recommended when benefits of control exceed the costs. The costs of control consist of the costs of labour, use of equipment, pesticides and yield loss due to wheel damage. The costs of pesticides are based on an average price for the products that can be used for the specific pest and disease complex. The profitability of control is calculated by subtracting the costs of a treatment from the damage prognosis for each organism. If profit is positive for one or more organisms, a treatment will be recommended. The prognosis of damage by the other species is evaluated once again, to assess the profitability of tank-mixing pesticides. Thus, in EPIPRE the assumption is made that damage is additive and that for most diseases and pests pesticides are $100 \%$ effective.

\section{Suggested improvements needed in the present version of EPIPRE}

\section{Sampling and incidence-severity relations}

The incidence of aphids is estimated in a sample of 100 tillers, whereas estimation of the incidence of the disease requires 40 tillers. Farmers tend to use the latter sample size for aphids as well. The risk involved needs to be evaluated and the sampling procedure adapted accordingly.

When sampling for 'leaf-spot diseases' a farmer lumps leaf blotch, ear blotch and Fusarium spp., as he is not trained to discriminate between them. Therefore farmers' observations on leafspot diseases are corrected with a region-dependent factor to account for the different effects of the three leaf-spot species on yield. It would be desirable to forecast the occurrence of these diseases, other than from historical survey data, and to have reliable data for the transformation of incidence into severity.

Instead of the current procedure with variable sampling dates, a system with sampling dates fixed on certain crop growth stages may be adopted: GS 31 (first node detectable), GS 41 (flag leaf sheath extending), GS 65 (anthesis halfway), GS 69-71 (anthesis complete-watery ripe) and GS 73-75 (early milk-medium milk). In case of high disease incidence at GS 31 (first node detectable) an additional sample may be recommended between GS 32 (second node detectable) and 37 (flag leaf just visible). Experience in recent years shows that in this way clarity can be gained without increasing the risk of 'missing' a sudden outbreak of a pest or disease.

\section{Relative growth rate}

The relative growth rate at a certain development stage can be made field-specific by correcting the standard value with crop and field-related factors. Adaptations that would improve the prediction of damage, include:

(1) correction for resistance of the cultivar. Cultivars are currently classified as resistant, moderately resistant or susceptible. Thus the variability among cultivars is neglected to a large 
extent. A more accurate prediction would improve the accuracy of the prediction and would do justice to the available diversity of resistances;

(2) correction for nitrogen available in the crop. More accurate quantification of the relation between the amount of nitrogen in the crop and the relative growth rate of the damaging organisms is desirable;

(3) correction for soil types. Currently the correction factors are based on results of nation-wide disease surveys. The correction factors are rough estimates only, as besides a soil and region effect annual variation is present in the data;

(4) correction for actual weather. Currently actual weather is not taken into account. Instead crop development stage and pest density are assumed to be perfect integrators of weather. However, especially for diseases which exhibit long latency periods like blotches and molds, actual weather may improve the forecast. A prerequisite is the availability of on-farm meteorological data;

(5) correction for pesticide residue. The assumption in the current version of EPIPRE that use of pesticides inhibits population development during the residue period is not realistic. However, to improve the models much more information is needed on the epidemiological effects of fungicides.

\section{Forecasting period}

Currently the period of time between the actual crop stage, the stage of peak population density and GS 83 (early doughy ripe) is expressed as fixed number of Julian days. In reality the rate of crop development is not constant but depends on temperature, day length, sowing date and the availability of fertilizer and water. As total damage is sensitive to changes in the value of the length of the forecasting period, improvement of this part of the system is useful. For this purpose a simulation model may be implemented (Reinink et al., 1986), which could also serve as an on-line check of the farmer's observation of crop growth stage.

\section{Damage relations}

The relations used to calculate yield loss from severity are sufficiently reliable, except those for stripe rust and blotches. The damage relation for stripe rust is the subject of continuing research. In future, the damage relation for blotches may be improved by results of a simulation study currently under way.

\section{Recommendation}

Calculation of the benefits of chemical control is based on the assumption that control of a species avoids all forecast damage. In reality, only a fraction of the population will be killed, the size depending on the conditions. Following the residue period, regrowth of the population occurs and a new epidemic may result. This may occur especially after treatments early in the season. Thus, the currently calculated benefits of control should be reduced by loss caused by the fraction of the population not killed. Until better data on the epidemiological effects of fungicides are available, a fixed fraction could be assumed.

In the cost-benefit analysis, no account is taken of the benefit of any side-effects of a chemical on harmful species which have a population density under the economic threshold. Realistically the calculation should include the effect of chemical treatment on all diseases and pests present. Currently the benefits and costs of immediate control are evaluated. The analysis may be extended to evaluation of immediate treatment as opposed to treatment after a certain time (e.g. one week) allowing an extra disease to be controlled effectively. This requires information on the probability of occurrence of specific diseases and aphids in a field. 


\section{Future developments}

Due to structural over-production of many commodities in the EC and increasing concern about the negative side-effects of present-day agriculture, maximization of yield is no longer the main objective of agricultural policy and research. In farming systems research, priority is given to fine-tuning of inputs without decreasing net output under a series of constraints concerning environment and social-economic objectives. Computerized decision-support systems may help the farmer in this process, by supplying him with up-to-date information on consequences of decisions in terms of financial outcome and environmental considerations.

Recently EPIPRE was incorporated into an information retrieval system which farmers could access from terminals in their homes. However, no integration of pest and disease control with other crop husbandry measures has been achieved yet, mainly due to lack of knowledge on the various interactions. For EPIPRE, important interactions exist with the rate of fertilizer application, sowing date of the crop and cultivar characteristics.

\section{Recommendations for research}

As indicated above, the current system is running the risk of becoming outdated by not reacting to the changing objectives of agriculture in The Netherlands. A new impulse is expected from research in the following topics:

phytopathology-better quantification of the effect of weather, soil type, fertilizer regime and cultivar sensitivity on the relative growth rate of pests and diseases; more realistic description of the instantaneous and residual effect of pesticides on the complex of pests and diseases;

crop physiology-analysis of crop development in relation to crop husbandry measures, especially fertilizer application;

farm economics - a more strategic approach to chemical control by evaluation of profitability of postponing control when expecting another infection to occur;

information management - analysis of the information content of EPIPRE by distinguishing data and process description. In this way a crop-dependent and a crop-independent part of the software is created which facilitates adaptation to other crops and other models. Moreover, maintenance of an existing system becomes more efficient.

\section{Evaluation des données physiologiques et épidémiologiques à incorporer dans le système EPIPRE}

Le système EPIPRE pour la protection intégrée du blé est basé sur des calculs en temps réel des coûts des traitements pesticides et des gains en rendement qui doivent en résulter. Il concerne la parcelle individuelle et utilise les résultats des notations de maladies et de ravageurs réalisées sur celle-ci par l'agriculteur lui-même. Ces chiffres sont convertis en indices de sévérité, à l'aide de formules spécifiques à chaque organisme nuisible, permettant de prévoir le développement de l'épidémie à partir d'un modèle exponentiel. L'intégrale de l'épidémie dans le temps, ajustée par un indice de dégâts spécifique à l'organisme nuisible, correspond aux pertes prévues dans l'année, en pourcentage de la récolte attendue. Le système ne préconise une intervention chimique que si le gain qui en résulte dépasse l'ensemble des coûts, y compris le prix du produit, la main-d'oeuvre, le matériel et les dégâts dus aux passages des appareils. La version actuelle du modèle demande encore une certaine amélioration en ce qui concerne la prévision des septorioses, la quantification des taux relatifs de croissance pour chaque parcelle, et les indices de dégâts dus à Puccinia striiformis et au complexe Mycosphaerella graminicola/Leptosphaeria nodorum. L'analyse de la rentabilité mérite également d'être revue. Aussi faudra-t-il faire appel dans un proche avenir à des contributions par secteur de recherche comme la phytopathologie, la physiologie végétale, l'économie rurale et la gestion des données. L'utilisation du modèle a, 
depuis 10 ans, permis de réduire les apports en pesticides, d'économiser sur les coûts de production et d'éviter une pollution de l'environnement. Toute amélioration du sytème devrait permettre d'en tirer encore plus d'avantages.

\section{Оценка физиологических и эпидемиологических данных для включения в единую систему}

Система EPIPRE, предназначенная для комплексной защиты пшеницы от заболеваний, основана на вычислениях в реальном масштабе времени различных затрат на пестицидную обработку, а также того выигрыша в прибавке урожая, который может быть с их помощью реализован. Система учитывает индивидуальные участки и использует результаты оценочного учета заболеваний и вредителей, выполненного на том же участке самим фермером. Эти числовые данные преобразуются системой в показатели серьезности с помощью формул, специально предусмотренных для каждого вредного организма и позволяющих прогнозировать развитие эпидемии по экспоненциальной модели. Модель интегрируется по времени, корректируется с помощью показателя ущерба применительно к конкретному вредному организму, соответствует потерям урожайности в течение всего вегетационного периода и выражается в процентном отношении от ожидаемого урожая. Системой предусматривается химическое вмешательство только в том случае, если вычисленная с ее помощью прибавка урожая превосходит общую совокупность затрат, включая стоимость препарата, рабочую силу, сельскохозяйственные машины и оборудование, а также ущерб, наносимый в результате прохода машин по сельскохозяйственным угодьям. В настоящее время действующий вариант модели требует еще некоторого усовершенствования в части прогнозирования септориозов, количественного выражения относительных показателей роста для каждого участка, а также показателей ущерба, вызываемого Puccinia striiformis и комплексом Mycosphaerella graminicola/Leptosphaeria nodorum. Анализ рентабельности при этом также заслуживает внимательного рассмотрения, поэтому в недалеком будущем предполагается широкое использование в системе самых различных областей научных исследований, таких как фитопатология, физиология растений, сельскохозяйственная экономика и обработка данных. Использование этой модели в течение уже 10 лет позволило сократить внесение пестицидов, провести существенную экономию себестоимости производства и избежать загрязнения окружающей среды. При этом любое усовершенствование системы позволит извлечь из нее еще более ощутимые преимущества.

\section{References}

BLOKKER, K.J. (1982) EPIPRE onder de Loep, een Voorlichtingskundig Onderzoek naar een Geautomatiseerd Adviseringssysteem in de Akkerbouw. Landbouwhogeschool, Vakgroep Voorlichtingskunde, Wageningen (NL).

DaAmen, R.A., Drenth, H., Hoek, J., Rossing, W., Stol, W. \& Wijnands, F.G. (1987) Het EPIPREadviesmodel. Een Kritische Analyse. PAGV-verslag no. 71. Lelystad (NL).

NACHMAN, G. (1981) A mathematical model of the functional relationship between density and spatial distribution of a population. Journal of Animal Ecology 50, 453-460.

RABBINGE, R. \& RIJSDIJK, F.H. (1983) EPIPRE: a disease and pest management system for winter wheat, taking account of micrometeorological factors. Bulletin OEPP/EPPO Bulletin 13, 297-305.

Reinink, K., JoRritsma I.T.M. \& DARWInKEL, A. (1986) Adaptation of the AFRC-wheat phenology model for Dutch conditions. Netherlands Journal of Agricultural Science 34, 1-13.

Rossing, W.A., SCHANS, J. \& ZADOKS, J.A. (1985) [The EPIPRE project: an experiment in project analysis for the protection of wheat]. Landbouwkundig Tijdschrift 97, 29-33 (in Dutch).

ZADOKs, J.C. (1984) Analyzing cost effectiveness of EPIPRE. Bulletin OEPP/EPPO Bulletin 14, 401-407. 